\title{
Breeding objectives for Holstein dairy cattle in Iran
}

\author{
A. Sadeghi-Sefidmazgi,, ${ }^{* 1,2}$ M. Moradi-Shahrbabak, ${ }^{*}$ A. Nejati-Javaremi,, S. R. Miraei-Ashtiani, ${ }^{*}$ \\ and P. R. Amert \\ *Department of Animal Science, University of Tehran, PO Box 3158711167-4111, Karaj, Iran \\ †AbacusBio Limited, PO Box 5585, Dunedin 9058, New Zealand
}

\section{ABSTRACT}

Trait-by-trait and multiple trait bioeconomic modeling were used to derive farm-specific economic weights (EW) for a wide range of traits under different production and economic circumstances to define breeding objectives for Holstein dairy cattle in Iran. Production parameters and economic data were gathered on 10 dairy farms from March 2008 to February 2010. The EW (economic values multiplied by gene expressions, in US dollars per unit of trait per calf born from sires of self-replacing females in planning horizon of $20 \mathrm{yr}$ ) were estimated to be $\$ 0.15$ per kilogram of milk yield; $\$ 1.36$ per kilogram of fat yield; $-\$ 1.02$ per kilogram of protein yield; $\$ 4.59$ per month of longevity; $-\$ 1.22$ per kilogram of mature cow weight; $-\$ 105.67$ for combined somatic cell score and clinical mastitis; $-\$ 1.35$ and $-\$ 0.28$ for percentage direct and maternal calving difficulties, respectively; $-\$ 3.98$ for percentage direct stillbirth; $-\$ 0.76$ per day of age at first calving; $-\$ 0.72$ per calving interval day; and $\$ 0.91$ for percentage 56 -d nonreturn rate on averages across investigated farms. The coefficient of variation of economic weights across the 10 farms was lowest for direct calving difficulty and highest for calving interval. The proposed Iranian selection index was compared with selection indices of major countries exporting semen to Iran. Average relative emphasis for production, durability, and health and reproduction, across all exporter countries, was $41,37.5$, and $21.5 \%$, respectively, whereas the respective values were 50,14 , and $36 \%$ for the Iranian index. Significant differences in selection indices may potentially decrease the utility of importation of semen as a means of achieving sustainable genetic progress in Iran. Results obtained in this study provide important information about economic values of traits that can be used to improve the Iranian national progeny testing program as well as importation rules for semen to Iran.

\footnotetext{
Received May 26, 2011.

Accepted January 9, 2012.

${ }^{1}$ Corresponding author: sadeghism@cc.iut.ac.ir

${ }^{2}$ Current address: Department of Animal Science, Isfahan University of Technology, PO Box 84156, Isfahan, Iran.
}

Key words: selection index, economic weight, dairy cattle

\section{INTRODUCTION}

Importation of Holstein registered heifers from Europe, the United States, and Canada during the 1970s and early 1980s was the precursor to the establishment of intensive dairy cow husbandry in Iran. An official livestock improvement organization called the Animal Breeding Centre of Iran (ABCI, Karaj, Iran), was developed and tasked with the further expansion and improvement of the Holstein population. A variety of traits including milk production, reproductive performance, and conformation traits have been systematically collected by ABCI. In Iran, national genetic evaluations are routinely carried out 2 times every year and EBV published on 5 production and 17 linear type traits. Dairy farmers receive the results of these evaluations, but long-term genetic and phenotypic trends of the traits might not be clearly illustrated or interpreted. Each year, approximately 80 young bulls enter into the progeny testing program, of which 12 to 20 bulls are selected as proven sires (Dadpasand et al., 2008). These young bulls are sons of top-ranked foreign bulls and mainly chosen according to daughter appearance, milk yield, and official consultant's experience and knowledge.

Multiple trait selection indexes that incorporate economic values $(\mathbf{E V})$ for individual traits are the most efficient way to maximize genetic improvement in overall breeding objectives (Hazel and Lush, 1942). For dairy cattle, EV for different production and functional traits have been reported (Gibson 1989; Groen, 1989; Bekman and van Arendonk, 1993; Visscher et al., 1994; Vargas et al., 2002; Kahi and Nitter, 2004; Wolfová et al., 2007; Komlósi et al., 2010) and applied to construct country-specific national genetic indexes (Miglior et al., 2005).

In Iran, an index including milk yield, fat percentage, and herd life was proposed first in 1997 (Shadparvar et al., 1997). This index was recalculated for the same traits, excluding fat percentage and including 2 traits 
(fat and protein yields) and named lifetime net income index. It became the national selection objective in 2006 (Sadeghi-Sefidmazgi et al., 2009). However, in addition to incompleteness of the proposed breeding goal, the lack of ongoing industry-wide discussion, communication, and interaction has resulted in minimal uptake of the lifetime net income index by $\mathrm{ABCI}$ and farmers.

The main objective of this study was to derive farmspecific EV for production and functional traits under different production and economic circumstances in Iran and to develop a national genetic index. This work also reports developments in the definition of 3 trait components or subindices for production, durability, as well as combined health and reproduction. The proposed Iranian selection index was compared with selection indices of major semen exporter countries to Iran. Using both trait-by-trait and multiple-trait bioeconomic modeling, EV for a variety of traits were estimated. The published methodology and models have been adapted to be relevant to Iranian production systems. In some instances, novel approaches have been outlined.

\section{MATERIALS AND METHODS}

\section{Production and Marketing Systems}

In Iran, the dairy cattle population has been increasing in both herd number and size. Iranian dairy farms vary in scale from small farms with less than 100 cows to large farms with 7,000 cows, with an overall average herd size of 680 cows. Holstein cows are the main dairy breed used in intensive dairy farm systems producing more than $90 \%$ of milk sold on the free market. Approximately 1 million Holstein cows have been registered, which represents $12.5 \%$ of the total national cattle population. Intensive production systems using open-shed and freestall barn housing systems are used, irrespective of herd size. Almost all of the farms employ nutritional experts and use feed rations relatively high in concentrates, with alfalfa and corn silage contributing roughage.

Currently in Iran, the milk pricing system is based on a price per kilogram of base milk (BM) and a percentage differential premium based on the fat and protein content of milk. There are large differences in milk payment systems among Iranian dairy processors. Most milk processors place minimal pricing emphasis on milk components, especially protein and SCC. The BM is defined as $1 \mathrm{~kg}$ of milk with $3.2 \%$ fat and $3 \%$ protein. Marketing plays an important role in the price of BM. However, the accessory payments for each percent of fat and protein are the same in the milk markets.

\section{General Model Description}

Four different groups of animals make up the total dairy herd population under Iranian production systems: calves, heifers, cows (including milking and dry cows), and fattened calves. The last group is omitted from the profit function because it relates to feedlot and beef production. Profit, calculated as total income minus total costs, was taken as the criterion of economic evaluation of the defined production system. The base unit for expression of profit is per cow calving per year. The currency that is used in Iran is rial (Rl). Hereafter, costs and prices are expressed in US dollars, assuming an exchange rate of 1 US $\$=10,000 \mathrm{Rl}$.

In this study, the total profit function considered was as follows:

$$
\mathrm{P}=\sum_{i=1}^{3} P_{i}=\sum_{i=1}^{3}\left(R_{i}-C_{i}\right),
$$

where $\mathrm{P}$ is total herd profit in dollars per cow per year; $R_{i}, C_{i}, P_{i}$ are revenues, costs, and profits, respectively from the given animal group per animal per year; $i$ $=1$ are female and male calves from birth to $3 \mathrm{mo}$ of age or death; $i=2$ are heifers from 3 mo of age to either age at first calving, selling, culling, or death; and $i=3$ are cows. Costs were divided into feed and nonfeed costs. Non-feed costs included labor, veterinary, breeding, housing, fuel, and insurance costs. Feed costs were based on energy and protein requirements, as mentioned in the section below. The equations used to calculate the profit from 3 animal groups are outlined in detail in the Appendix.

\section{Data Description}

This study used data from 10 large dairy farms distributed in 3 provinces (Isfahan, Tehran, and Khorasan) of Iran where most industrial dairy farms are located. All participating farms are systematically recorded by ABCI. Therefore, production data were either extracted from a large data set provided by ABCI or gathered with a questionnaire. Economic data were provided by farmers via a questionnaire or estimated by cost and revenue modeling. Descriptive statistics for production data and variables considered for calculation of $\mathrm{EV}$ are summarized in Table 1. Data sources used for deriving economic input parameters were based on the marketing circumstances in 2008 and 2009. Descriptive statistics of unit prices and costs considered for calculation of EV are summarized in Table 2. 
Table 1. Descriptive statistics for production data and variables considered for calculation of economic values

\begin{tabular}{|c|c|c|c|c|c|}
\hline Production item & Abbreviation & Mean & $\mathrm{SD}$ & Minimum & Maximum \\
\hline 305-d milk yield, $\mathrm{kg}$ & MY & 9,099 & 399 & 8,454 & 9,548 \\
\hline 305 -d fat yield, kg & FY & 299 & 21 & 253 & 335 \\
\hline 305-d protein yield, $\mathrm{kg}$ & PY & 271 & 13 & 250 & 290 \\
\hline Age at first calving, mo & $\mathrm{AFC}$ & 25.0 & 0.7 & 24.0 & 26.6 \\
\hline Calving interval, d & ClvI & 428.2 & 15.0 & 399.0 & 441.1 \\
\hline Stillbirth, \% & SB & 5.02 & 0.33 & 4.48 & 5.79 \\
\hline Calf mortality, $\%$ & CMo & 3.71 & 0.63 & 2.23 & 4.79 \\
\hline $\begin{array}{l}\text { Involuntary culling rate of calves } \\
\text { from birth to } 3 \text { mo of age }\end{array}$ & CICR & 0.07 & 0.04 & 0.00 & 0.16 \\
\hline Proportion of male calves sold to feedlot & CVCR & 0.91 & 0.05 & 0.80 & 1.00 \\
\hline Number of female calves reared per cow per year & NHR & 0.39 & 0.01 & 0.37 & 0.41 \\
\hline Survival rate of heifers from 3 mo of age to calving & SR & 0.99 & 0.00 & 0.99 & 1.00 \\
\hline
\end{tabular}

\section{Energy and Protein Costs}

In this study, feed cost components were $\mathrm{NE}_{\mathrm{L}}$ and MP. Costs per Mcal of $\mathrm{NE}_{\mathrm{L}}\left(\mathrm{C}_{\mathrm{NE}_{\mathrm{L}}}\right)$ and per gram of MP $\left(\mathrm{C}_{\mathrm{MP}}\right)$ were calculated using the least squares equation as

$$
\mathbf{X}^{\prime} \mathbf{X} \boldsymbol{\beta}=\mathbf{X}^{\prime} \mathbf{y} \Rightarrow \boldsymbol{\beta}=\left(\mathbf{X}^{\prime} \mathbf{X}\right)^{-1} \mathbf{X}^{\prime} \mathbf{y}=\left(\begin{array}{c}
\mathrm{C}_{\mathrm{NE}_{\mathrm{L}}} \\
\mathrm{C}_{\mathrm{MP}}
\end{array}\right),
$$

where $\mathrm{X}^{\prime}$ is the transpose of $\mathbf{X}$, which is an incidence matrix with $\mathrm{N}$ rows (number of feedstuffs used on each farm) and 2 columns ( $\mathrm{NE}_{\mathrm{L}}$ and MP per kilogram of $\mathrm{DM}$ of each food), $\boldsymbol{\beta}$ is the unknown vector of unit costs of $\mathrm{NE}_{\mathrm{L}}$ and $\mathrm{MP}$, and $\mathbf{y}$ is a vector of corresponding feed prices expressed per kilogram of DM. Feed ingredients were determined based on NRC (2001). Average prices per kilogram of DM for forage and concentrate were $\$ 0.27$ and $\$ 0.52$, respectively.

\section{Derivation of EV}

The EV of each trait is defined as the change in profit per unit change of that trait, given no change in any other trait (Groen, 1989). In multiple trait bioeconomic modeling, the economic effect of each trait on profit was defined as the partial derivative of the total profit

Table 2. Descriptive statistics for unit prices and costs considered for calculation of economic values

\begin{tabular}{|c|c|c|c|c|c|}
\hline Item & Abbreviation & Mean & $\mathrm{SD}$ & Minimum & Maximum \\
\hline \multicolumn{6}{|l|}{ Price } \\
\hline Base milk price, $\$ / \mathrm{kg}$ & pbm & 0.46 & 0.02 & 0.41 & 0.48 \\
\hline Male calf price, $\$ /$ calf & bcp & 389 & 36 & 324 & 470 \\
\hline Accessory payment for milk fat, $\$ / \mathrm{kg}$ & paf & 3.0 & & & \\
\hline Accessory payment for milk protein, $\$ / \mathrm{kg}$ & рар & 1.0 & & & \\
\hline Price per kilogram for culled calves, $\$$ & plw & 3.4 & & & \\
\hline \multicolumn{6}{|l|}{ Cost } \\
\hline Costs per Mcal of $\mathrm{NE}_{\mathrm{L}}, \$$ & $C_{N E L}$ & 0.18 & 0.01 & 0.16 & 0.19 \\
\hline Costs per kilogram of MP, $\$$ & $C_{M P}$ & 0.71 & 0.09 & 0.58 & 0.87 \\
\hline Base milk costs, $\$ / \mathrm{kg}$ & $\mathrm{cbm}$ & 0.34 & 0.02 & 0.32 & 0.37 \\
\hline Accessory costs for milk fat, $\$ / \mathrm{kg}$ & caf & 1.65 & 0.08 & 1.45 & 1.73 \\
\hline Accessory costs for milk protein, $\$ / \mathrm{kg}$ & cap & 2.10 & 0.18 & 1.81 & 2.29 \\
\hline Calf-rearing costs, $\$ /$ calf & $\operatorname{crc}$ & 549 & 146 & 304 & 766 \\
\hline
\end{tabular}


function with respect to the trait, whereas in trait-bytrait bioeconomic modeling, the economic effect of each trait was measured independently.

\section{Gene Expression}

When genes are expressed, their effects can be measured as genetic improvement in various traits at different times on different numbers of animals (e.g., offspring or descendents). Genetic superiority expressed sooner rather than later is typically preferred because of the opportunity cost of delayed benefits. The gene flow methodology as presented by Amer et al. (2001) for beef cattle was modified in this study to calculate gene expressions (GE) for different categories of animal traits in Holstein dairy cattle of Iran. Lactation traits are expressed once per calving interval in female descendants of the bull, whereas direct calving traits are expressed in all descendants, and also sometimes affect the mates of the bull. Some traits are expressed in replacement females, some in slaughtered calves, and some in cows at the time of culling. The GE were counted over 4 generations and expressed per calf born for sires of self-replacing females under the assumptions of a cull for age threshold of $10 \mathrm{yr}$, and a planning horizon of $20 \mathrm{yr}$. In the current economic conditions of Iran, the discount rate would be negative because the inflation rate is higher than the interest rate charged to farmers for borrowing money. Therefore, a discount rate of zero was assumed for the current index, but the methodology allows this to be easily updated in the future for a nonzero discount rate.

\section{Calculation of Economic Weights}

Economic weights $(\mathbf{E W})$ were calculated by multiplying the EV by the number of GE. Because a zero discount rate was applied, the EW did not take into account the different time the traits were expressed during an animal's life (Groen et al., 1997).

\section{Milk Production Traits}

For milk traits (milk, fat, and protein yields), the EV were derived by taking the first derivative of the profit function [1] with respect to each trait for which the EV was required. This is effectively equivalent to taking the difference between revenues and costs of producing $1 \mathrm{~kg}$ of each product because no supply quotas exist for dairy farms in Iran.

The effect of an increase in 305-d milk yield on the milk yield from the whole lactation was also considered as extra income contributing to the EV of 305-d milk yield because with quite long calving intervals, a genetic improvement in 305-d milk yield should lead to even more milk production over the full lactation period. The genetic regression coefficient of total lactation milk yield on 305-d milk yield was estimated to be 1.3 and used as a multiplier for profit per kilogram of milk yield.

Expenses associated with milk production (BM) were calculated considering feed requirements and labor, veterinary, breeding, housing, fuel, and insurance costs. For fat and protein yields, only costs associated with $\mathrm{NE}_{\mathrm{L}}$ and MP requirements were considered (NRC 2001). Energy needs to produce $1 \mathrm{~kg}$ of butterfat and milk protein were assumed to be 9.29 and 5.47 Mcal, respectively. To produce $1 \mathrm{~kg}$ of net protein in milk, $1.47 \mathrm{~kg}$ of MP in feed was also required (NRC 2001). Expenses associated with production of BM, fat, and protein were $\$ 0.34, \$ 1.65$ and $\$ 2.10$ respectively.

\section{Longevity}

Multiple-trait bioeconomic modeling was used to estimate the EV for longevity. The first partial derivatives of the total profit function (equation 1), with respect to longevity, gave the corresponding EV. Heifer-rearing costs and sale prices, salvage values from culled cows and heifers, the involuntary culling rate of heifers, cow mortality, and the current herd average value for longevity were components that influenced the EV of longevity.

\section{Cow Mature Weight}

Cow mature weight was defined as cow weight after the third calving and was assumed to be $680 \mathrm{~kg}$ in the base situation. The prediction methodology follows that of Byrne et al., (2010) in the calculation of the EV of ewe mature weight. The economic implications of higher calving interval maintenance feed requirements for the adult female, higher feed requirements for maintaining and growing the replacement female, as well as a heavier carcass weight of the cull female were all modeled separately.

The feed cost to meet calving interval maintenance requirements per kilogram of additional cow live weight was predicted from daily $\mathrm{NE}_{\mathrm{L}}$ and $\mathrm{MP}$ requirements for cow maintenance presented in NRC (2001) and corresponding nutrient costs (from equation 2). The effect of a $1-\mathrm{kg}$ increase in mature weight on replacement heifer feed requirements and, therefore, the feed costs of rearing a replacement, was calculated as the increase in energy and protein requirements for growth and maintenance (NRC, 2001) from birth to third lactation.

Additional value captured from a heavier cull cow live weight is calculated at a cull cow price of $\$ 2.4$ per 
Table 3. Frequencies, calving difficulty category effects, and total calving costs (relative to a no-assistance calving), on average, across 10 farms

\begin{tabular}{|c|c|c|c|}
\hline Parameter & No assistance & Difficult & Very difficult \\
\hline Frequency, \% & 78.5 & 16.2 & 5.3 \\
\hline Milk losses, $\mathrm{kg}$ & 0 & 122.6 & 351.7 \\
\hline Milk cost, $\$ / \mathrm{kg}$ & 0.46 & 0.46 & 0.46 \\
\hline Longer calving interval, $\mathrm{d}$ & 0 & 9.2 & 21.6 \\
\hline Calving interval cost, $\$ / \mathrm{d}$ & 0.79 & 0.79 & 0.79 \\
\hline Probability of cow culled to abattoir, $\%$ & 0 & 3.0 & 3.0 \\
\hline Culled cow cost, $\$$ & 890 & 890 & 890 \\
\hline Probability of dead cow, $\%$ & 0 & 0.4 & 2.3 \\
\hline Adult cow cost, $\$$ & 2,300 & 2,300 & 2,300 \\
\hline Stillbirth, \% & 0 & 5.3 & 21.5 \\
\hline Newborn calf cost, $\$$ & 500 & 500 & 500 \\
\hline Veterinary service, $\mathrm{h}$ /calving & 0 & 1.0 & 3.0 \\
\hline Cost of veterinary service, $\$ / \mathrm{h}$ & 3.33 & 3.33 & 3.33 \\
\hline Farm labor required, $\mathrm{h} /$ calving & 0 & 2.0 & 10.0 \\
\hline Labor cost, $\$ / \mathrm{h}$ & 0.67 & 0.67 & 0.67 \\
\hline Total calving cost, $\$$ & 0 & 155.24 & 435.13 \\
\hline
\end{tabular}

$\mathrm{kg}$ of live weight. It was assumed that $2.3 \%$ of mature cows died on farm and, therefore, additional revenues from slaughter cows were corrected for the mortality. The separate cow mature weight EV for calving interval cow maintenance, heifer-rearing costs, and cull cow salvage value were combined into a single EW using relative GE for calving interval cow, heifer, and cull cow traits, respectively.

\section{SCC}

The methodology used to calculate the EV for SCS and clinical mastitis (CM) has been described by Sadeghi-Sefidmazgi et al. (2011). Clinical mastitis is not recorded in Iran. Therefore, no estimates are available for the correlation between CM and SCS. An attempt was made to combine $\mathrm{EV}$ of these traits based on genetic parameters from the international literature as $\mathrm{EV}_{\mathrm{SCS}}+\mathrm{b}_{\mathrm{CM} \text {.SCS }} \times \mathrm{EV}_{\mathrm{CM}}$, where $\mathrm{EV}_{\mathrm{SCS}}$ and $\mathrm{EV}_{\mathrm{CM}}$ are $\mathrm{EV}$ for SCS and CM, respectively, whereas $\mathrm{b}_{\mathrm{CM}, \mathrm{SCS}}$ is the genetic regression coefficient of CM on SCS.

Assuming a genetic correlation of 0.7 (Coffey et al., 1986) and genetic standard deviation of 0.08 for CM and 0.23 for SCS (Cole and VanRaden, 2010), $\mathrm{b}_{\mathrm{CM}, \mathrm{SCS}}$ was estimated to be 0.2435 , representing the expected genetic change in the number of cases of CM per cow per year per unit genetic change in SCS.

Both SCS and CM are calving-interval cow traits. Thus, the EW are the same as the EV because calvinginterval cow traits have relative GE coefficients of unity.

\section{Calving Difficulty}

Calving performance is recorded by dairy producers in Iran. Because of low accuracy in the available data set, biological input parameters used for the calcula- tions were taken from the international literature (Dematawewa and Berger, 1997; López de Maturana et al., 2007). In this study, 3 calving difficulty categories were assumed to be $1=$ no assistance, $2=$ difficult (assisted by 1 or 2 laborers), and $3=$ very difficult (needed more assistance and cesarean). Economic parameters used in this study were derived from market prices or supplied by veterinarians and specialists.

Cost components were considered for calving score categories 2 and 3, expressed as a difference from the cost of an easy calving (calving score 1). Frequencies of calving ease scores, the effects of each calving difficulty category on different cost components, and total calving costs are summarized in Table 3.

The EV for calving difficulty on the liability scale was computed according to the methodology proposed by Meijering (1986), and was then converted to the incidence scale as described by Amer et al. (2001). To estimate the full EV for calving difficulty (FEV), losses in milk yield, decreases in fertility measured as longer calving interval, cow deaths and involuntary culling, stillbirth, as well as farm labor and veterinary costs were considered. For the EV of daughter calving difficulty (DEV), the economic impacts of difficult calving on traits already included in the breeding goal were excluded to avoid double counting. Thus, it is assumed that reductions in traits such as milk yield in daughters of sires whose daughters have a high incidence of difficult calving will be reflected in their EBV for milk traits and penalized in this way. Therefore, DEV includes farm labor and veterinary costs only.

The EW for direct calving difficulty was calculated as $\mathrm{X}_{\text {MBmate }} \times \mathrm{FEV}+\mathrm{X}_{\text {MBdgt }} \times \mathrm{DEV}$, where $\mathrm{X}_{\text {MBmate }}$ are direct expressions that affect the mates that the bull is mated to and $\mathrm{X}_{\mathrm{MBdgt}}$ are direct expressions that affect the descendants of daughters of the bull. 
The EW of maternal calving difficulty was calculated as $2 \times \mathrm{X}_{\text {MBdgt }} \times \mathrm{DEV}$. Daughter component calf at birth was doubled because the trait is expressed once per calving interval in sire's daughters.

\section{Stillbirth Rate}

A calf born dead or that dies within $48 \mathrm{~h}$ after birth was defined as being a stillbirth. The EV of the stillbirth rate was expressed as the opportunity cost of the calf, which is equal to the price obtainable for a newborn calf. Male and female calf values were assumed to be $\$ 400$ and $\$ 600$, respectively. The weighted average value was calculated assuming that $58 \%$ of stillbirths were male to account for higher rates of dystocia related to mortality in males compared with female calves (Amer et al., 2001). Then, the EV was calculated per percentage and per cow per year with a correction for calving rate. The EW of direct stillbirth rate was calculated as the EV multiplied by the relative GE coefficient for calf traits at birth.

\section{Age at First Calving}

The EV for age at first calving was estimated from the extra expense caused by a 1-d delay in first calving so as to reflect the changes in profit for a marginal change.

According to dietary guidelines suggested by NRC (2001) for transitioning a heifer weighing $625 \mathrm{~kg}$ with conceptus and entering first lactation during the later dry period or close-up, $10.6 \mathrm{~kg}$ of DM, 16.9 Mcal of $\mathrm{NE}_{\mathrm{L}}$ and $1,027 \mathrm{~g}$ of MP are required daily. A further allowance of $20 \%$ was added to feeding costs to account for rearing costs that are independent of feed requirements.

To express the EV per cow per year, rearing costs were corrected for sex ratio, calving rate, stillbirth, preand postweaning survival rates, and heifer mortality. The EW of age at first calving was calculated as the EV multiplied by the relative GE coefficient for heifer traits.

\section{Calving Interval}

The EV of calving interval was calculated as the first partial derivative of the total profit function (equation 1) with respect to calving interval. Revenues and costs from calves as well as heifers contributed to the estimation of the EV for calving interval because a longer calving interval decreases annualized revenues from surplus calves. Increases in milk yield because of the longer calving interval were considered as extra income contributing to the EV of calving interval. The regression coefficient of milk yield on calving interval was estimated to be $2.32 \mathrm{~kg}$ per day. To avoid double counting of the EV of nonreturn rate, the longer calving interval was assumed to be due to factors that do not affect nonreturn rate, such as postpartum anestrous and first-heat detection rates. The EW of calving interval is equal to the EV because the trait is expressed once per calving interval by cows and so has a relative GE coefficient of unity.

\section{6-d Nonreturn Rate}

The 56-d nonreturn rate (NR56) was scored as 0 or 1 , based on whether the cow had a second insemination within $56 \mathrm{~d}$ after the first one. Table 4 lists the assumptions about the biological, management, and economic input parameters used in bioeconomic modeling to calculate the EV for NR56. It was assumed that cows showed an estrous cycle on each 21-d period. Therefore, 2 estrous cycles were expected within $56 \mathrm{~d}$ in the absence of conception, and nonpregnant cows were assumed to be kept on a farm for $300 \mathrm{~d}$ following calving. Therefore, a maximum number of 10 estrous cycles would be possible for any cow.

In the calculation of the EV for NR56, only benefits associated with decreased units of semen needed per pregnancy with higher NR56 were considered. Additional benefits associated with NR56 that are included in longevity (reduced requirements for replacements), and calving interval (higher average herd yields because of more ideal lactation lengths per cow), were explicitly excluded from the estimation of the EV of NR56, to avoid double counting. This is because longevity and calving interval were already included in the breeding objective as traits in their own right.

In the calculation of average costs per insemination, it was assumed that only $8 \%$ of animals are inseminat-

Table 4. Biological, management, and economic input parameters used for bioeconomic modeling of nonreturn rate 56

\begin{tabular}{lc}
\hline Variable & Value \\
\hline Estrous cycle, d $^{1}$ & 21 \\
Conception rate $^{1}$ & 0.40 \\
Heat detection rate $^{2}$ & 0.50 \\
Pregnancy rate $^{3}$ & 0.20 \\
Conventional domestic semen dose price, $\$_{\text {Conventional imported semen dose price, } \$}$ & 6 \\
Sexed imported semen dose price, $\$$ & 25 \\
Average costs per insemination, $\$$ & 62.5 \\
\hline
\end{tabular}

${ }^{1}$ Conception rate was the number of cows that conceive divided by the number bred at the time of pregnancy check.

${ }^{2}$ Heat detection rate was number of cows bred divided by the number of cows eligible to get bred over a 21-d period.

${ }^{3}$ Pregnancy rate was number of cows that became pregnant divided by the number of cows eligible to get pregnant over a 21-d period and also can be calculated as conception rate $\times$ heat detection rate in percent. 
ed with sexed semen, $72 \%$ with conventional imported semen, and the remaining $20 \%$ with domestic semen. Prices for each kind of semen per dose are shown in Table 4.

The EV of NR56 ( $\left.E V_{N R 56}\right)$ was calculated indirectly as a 1 percentage unit increase in pregnancy rate and its effects on number of services and proportion of cows showing pregnancy $56 \mathrm{~d}$ after first service as

$E V_{N R 56}=\frac{\delta I N S}{\delta P R} \times \frac{\delta P R}{\delta N R 56} \times$ average costs per service $(\$)$,

where $\frac{\delta I N S}{\delta P R}$ gives the change in the number of insemination services $(I N S)$ needed per 1 percentage unit change in pregnancy rate $(P R)$, whereas $\frac{\delta P R}{\delta N R 56}$ gives the percentage change in $P R$ with a 1 percentage unit change in NR56. The product of these 2 values gives the change in number of services per 1 percentage unit increase in NR56, which is multiplied by the average costs per insemination service to give $E V_{N R 56}$.

The EW and EV of NR56 are equivalent because the trait is expressed once per calving interval by cows and so has a relative GE coefficient of unity.

\section{Genetic Standard Deviations}

Genetic standard deviations (GSD) were taken from analyses of the Iranian Holstein dairy cattle population (Nilforooshan and Edriss, 2004; Dadpasand Taromsari, 2005; Toghiani Pozveh et al., 2009) or from the literature (Hansen et al., 2004; González-Recio and Alenda, 2005; Perez-Cabal et al., 2006). For binomial traits, GSD were estimated so that they would be relevant to the Iranian Holstein population. Based on the trait probability (p) in the population, phenotypic variance was estimated as $\mathrm{p} \times \mathrm{q}$ (where $\mathrm{q}=1-\mathrm{p})$. Using the method described by Dempster and Lerner (1950), heritability on the underlying scale was converted onto the observed scale. Therefore, GSD for binomial traits were calculated as the square root of transformed heritability $\times \mathrm{p} \times(1-\mathrm{p})$.

\section{Relative Emphasis}

Differences in production models, definitions of traits, and assumptions about management system effects on the genetic improvement of particular traits make a direct comparison of EV among different countries very difficult (Groen et al., 1997; Wolfová et al., 2007). To compare the proposed Iranian selection index with selection indices of other countries, relative emphasis was calculated using equation 4 :

$$
R E_{i}=\frac{E W_{i} \times G S D_{i}}{\sum_{i=1}^{t}\left|E W_{i} \times G S D_{i}\right|} \cdot 100,
$$

where $R E_{i}, E W_{i}$, and $G S D_{i}$ are relative emphasis, economic weight, and genetic standard deviation for the $i$ th trait, respectively, and $t$ is the number of traits in the breeding objective.

\section{RESULTS}

Table 5 shows values derived for absolute and relative GE coefficients for sires of self-replacing females for calving-interval cow traits, traits of the calf at birth and slaughter, traits of heifers, and traits of cows at culling. The GE for total direct components of the calving-difficulty traits at birth are split into mate and daughter components because one-half of the bull genes are expressed as birth direct traits in the calf born (mate component), but a proportion of these calves go on to become heifer replacements (daughter component).

Calving-interval cow traits show the greatest number of expressions. Expressions at slaughter are lower than

Table 5. Values of gene expression (GE) of a sire's genes for traits expressed at different life cycle stages (per calf born)

\begin{tabular}{llcc}
\hline & & \multicolumn{2}{c}{ Value } \\
\cline { 3 - 4 } Trait category & Abbreviation & Absolute $^{*}$ Relative $^{1}$ \\
\hline Calving interval cow & $\mathrm{X}_{\mathrm{MA}}$ & 1.07 & 1.00 \\
Calf at birth & $\mathrm{X}_{\mathrm{MB}}$ & 1.03 & 0.96 \\
Mate component & $\mathrm{X}_{\mathrm{MBmate}}$ & 0.50 & 0.47 \\
Daughter component & $\mathrm{X}_{\mathrm{MBdgt}}$ & 0.53 & 0.50 \\
Calf at slaughter & $\mathrm{X}_{\mathrm{MS}}$ & 0.43 & 0.40 \\
Heifer & $\mathrm{X}_{\mathrm{MH}}$ & 0.47 & 0.44 \\
Culled cow & $\mathrm{X}_{\mathrm{MC}}$ & 0.46 & 0.43 \\
\hline
\end{tabular}

${ }^{1}$ The GE values are scaled so that the number of calving interval cow expressions equals 1 . 
Table 6. The mean, standard deviation, minimum (Min), maximum (Max), and coefficient of variation of economic weights (in US dollars per unit of trait per calf born) calculated for the 12 evaluated traits across 10 large dairy farms

\begin{tabular}{|c|c|c|c|c|c|}
\hline Item & Mean & SD & Min & Max & $\mathrm{CV}$ \\
\hline Milk yield, kg & 0.15 & 0.02 & 0.12 & 0.19 & 13.3 \\
\hline Fat yield, kg & 1.36 & 0.08 & 1.27 & 1.55 & 5.9 \\
\hline Protein yield, $\mathrm{kg}$ & -1.02 & 0.12 & -1.23 & -0.81 & -11.8 \\
\hline Longevity, mo & 4.59 & 0.84 & 3.57 & 6.01 & 18.3 \\
\hline Mature BW, kg & -1.22 & 0.06 & -1.28 & -1.10 & -4.9 \\
\hline $\mathrm{SCS}^{1}$ & -105.67 & 46.03 & -224.20 & -135.82 & -43.6 \\
\hline Direct calving difficulty $^{2}$ & -1.35 & 0.04 & -1.41 & -1.24 & -3.0 \\
\hline Maternal calving difficulty $^{2}$ & -0.28 & - & - & - & - \\
\hline Direct stillbirth, \%-unit & -3.98 & 0.14 & -4.26 & -3.86 & -3.5 \\
\hline Age at first calving, $\mathrm{d}$ & -0.76 & 0.05 & -0.82 & -0.69 & -6.6 \\
\hline Calving interval, d & -0.72 & 0.44 & -1.29 & 0.34 & -61.1 \\
\hline Nonreturn rate $56, \%$-unit & 0.91 & - & - & - & — \\
\hline
\end{tabular}

${ }^{1}$ Combination of clinical mastitis and SCS economic values by genetic regression coefficient.

${ }^{2}$ Per 1 percentage unit increase in the percentage of cows experiencing hard or very hard calving performance.

expressions at birth because not all calves survived. Traits of heifers and culled cows have the same expressions under the assumption of a discount rate of zero because they are only expressed once in an animal's lifetime and related to herd-replacement policy.

The mean, standard deviation, and minimum and maximum of EW calculated for the 12 evaluated traits (milk, fat and protein yields, longevity, mature cow weight, SCS, direct and maternal calving difficulty, direct stillbirth, age at first calving, calving interval, and NR56) across 10 large dairy farms are given in Table 6. The coefficient of variation of EW across the 10 farms was lowest for direct calving difficulty and highest for calving interval.

An increase in 305-d milk, fat, and protein yields by $1 \mathrm{~kg}$ caused a change in profit of $\$ 0.15, \$ 1.36$, and -\$1.02 per calf born, respectively. Negative EW of protein yield suggested that decreasing the trait would bring better profit to the system, reflecting high feed requirements associated with protein synthesis and a lack of market incentive for dairy farmers to produce protein. The EW for longevity varied between farms from $\$ 3.57$ to $\$ 6.01$, with an average of $\$ 4.59$ per calf born per month of herd life.

An increase of $1 \mathrm{~kg}$ in cow mature weight was predicted to have an average EV of $-\$ 1.58$ per cow per year, varying from $-\$ 1.67$ to $-\$ 1.44$ across investigated farms (Table 7). By accounting for differences in the number of GE of the component traits per sires of selfreplacing females, the EW for cow mature weight was estimated to be $-\$ 1.22$ per cow per year, on average, with a standard deviation of $\$ 0.06$ across farms.

An increase in the average SCS by 1 was associated with an increase in the number of CM cases per cow

Table 7. Traits in 3 subindices including economic values, genetic expression coefficients, economic weights (economic values multiplied by gene expressions), the genetic standard deviation, and relative emphasis for each trait

\begin{tabular}{|c|c|c|c|c|c|c|}
\hline $\begin{array}{l}\text { Trait component } \\
\text { (subindex) }\end{array}$ & Objective trait & $\begin{array}{l}\text { Economic } \\
\text { value }^{1}\end{array}$ & $\begin{array}{c}\text { Gene } \\
\text { expression }\end{array}$ & $\begin{array}{l}\text { Economic } \\
\text { weight }^{2}\end{array}$ & $\begin{array}{l}\text { Genetic } \\
\text { SD }\end{array}$ & $\begin{array}{c}\text { Relative } \\
\text { emphasis, \% }\end{array}$ \\
\hline \multirow[t]{2}{*}{ Production } & Milk yield, $\mathrm{kg}$ & 0.15 & 1 & 0.15 & 561.7 & 36 \\
\hline & Fat yield, $\mathrm{kg}$ & 1.36 & 1 & 1.36 & 14.9 & 8 \\
\hline \multirow[t]{2}{*}{ Durability } & Longevity, mo & 10.13 & 0.44 & 4.59 & 3.5 & 7 \\
\hline & Mature BW, kg & -1.58 & Complex & -1.22 & 13.32 & -7 \\
\hline \multirow[t]{5}{*}{ Health and reproduction } & $\mathrm{SCS}^{3}$ & -105.67 & 1 & -105.67 & 0.23 & -10 \\
\hline & Direct stillbirth, \%-unit & -4.14 & 0.96 & -3.98 & 4.9 & -8 \\
\hline & Age at first calving, d & -1.73 & 0.44 & -0.76 & 25.1 & -8 \\
\hline & Calving interval, d & -0.72 & 1 & -0.72 & 16.5 & -5 \\
\hline & Nonreturn rate $56, \%$-unit & 0.91 & 1 & 0.91 & 8.6 & 3 \\
\hline
\end{tabular}

\footnotetext{
${ }^{1}$ Economic values were expressed in US dollars per unit of trait per cow per year.

${ }^{2}$ Economic weights were expressed in US dollars per unit of trait per calf born from sires of self-replacing females.

${ }^{3}$ Combination of clinical mastitis and SCS economic value by genetic regression coefficient.

${ }^{4}$ Per 1 percentage unit increase in the percentage of cows experiencing hard or very hard calving performance.
} 
per year of 0.2435 cases. The ranges of EV calculated for CM and SCS were reported in a previous study (Sadeghi-Sefidmazgi et al., 2011). As shown, on average, the EV of CM and SCS were $-\$ 80.09$ and $-\$ 86.17$ per cow per year, respectively. Combining these into an EV for SCS produced a figure of $[-\$ 86.17+(0.2435$ $\times-\$ 80.09)]=-\$ 105.67$ per cow per year (Table 7 ). The mean of the combined EW for SCS was out of the ranges of values reported here for the investigated farms because it was calculated based on the EV of SCS for the whole population (Sadeghi-Sefidmazgi et al., 2011).

On average, EW calculated for direct and maternal calving difficulties were $-\$ 1.35$ and $-\$ 0.28$ per calf born, respectively, for a 1 percentage unit increase in cows experiencing either hard or very hard calvings. The estimated EW for direct calving difficulty varied from $-\$ 1.41$ to $-\$ 1.24$ across investigated farms with a standard deviation of $\$ 0.04$, whereas the same EW for maternal calving difficulty was observed for all farms because they had the same input parameters.

The EW of a 1 percentage unit increase in direct stillbirth rate varied from $-\$ 4.26$ to $-\$ 3.86$ per calf born across the 10 farms, with an average of $-\$ 3.98$ per calf born. An increase in age at first calving by $1 \mathrm{~d}$ had an EW of $-\$ 0.76$, on average, and varied between farms from $-\$ 0.82$ to $-\$ 0.69$ per calf born. An increase in calving interval by $1 \mathrm{~d}$ had an EW of $-\$ 0.72$, on average, and varied between farms from $-\$ 1.29$ to $\$ 0.34$ per calf born.

With the assumption of a $20 \%$ pregnancy rate, 2.30 insemination services were required per pregnancy. Increasing the pregnancy rate by 1 percentage unit (from 20 to $21 \%$ ) would increase NR56 by 2.2 percentage units (from 61.6 to $63.8 \%$ ), thereby decreasing the number of inseminations per pregnancy by 0.08 (from 2.30 to 2.22). Assuming the same input parameters for all farms resulted in the same EW of $\$ 0.91$ per calf born for a 1 percentage unit increase in NR56.

Table 7 describes the traits in 3 subindices, including EV, GE coefficients, EW (EV multiplied by number of $\mathrm{GE}$ ), the genetic standard deviation, and relative emphasis for each trait. The most important trait was milk yield, which contributed $36 \%$ of relative emphasis over all traits. The second most important trait, combined SCS, accounted for 10\%. Fat yield, direct stillbirth, and age at first calving contributed approximately $8 \%$ of relative emphasis, whereas protein yield, calving interval, mature cow weight, and NR56 contributed 3 to $7 \%$. The relative importance of direct calving difficulty was $2 \%$. The lowest economic impact was found for maternal calving difficulty $(0.1, \approx 0 \%)$. Summing up the relative emphasis over the 3 trait components, the shares of milk production, durability, and health and reproduction traits were 50,14 , and $36 \%$, respectively.

\section{DISCUSSION}

In this study, farm-specific EW were determined using a combination of trait-by-trait and multiple-trait bioeconomic models for a wide range of traits across 10 dairy farms. The resulting breeding objective should guide selection pressure among traits through application via a selection index. It can also provide direction for prioritization of trait recording, selection strategies, and mating systems.

Breeding objectives have been presented in the form of 3-goal trait group subindex components. These subindexes provide commercial farmers with the ability to adjust breeding emphasis toward specific market outcomes or address key production aspects of their particular farming system (Byrne et al., 2010).

In contrast to other studies (e.g., Amer et al., 2001; Kahi and Nitter, 2004), in the present study, the costs of feed protein requirements were considered in addition to the feed costs of energy requirements. In Iran, protein is typically supplied by concentrates that are more expensive than forages. Therefore, ignoring protein costs would result in underestimation of feed costs. Average costs per megacalorie of $\mathrm{NE}_{\mathrm{L}}$ and grams of $\mathrm{MP}$ were estimated under assumption of the same proportion of main feed consumption on each farm. This was mainly due to lack of information, which may affect the estimates.

The high observed variation in EW for milk yield can be attributed to different milk sale prices, in which marketing plays an important role. Differences in production costs, including feeding, labor, and housing, also contributed to variation in the EW of milk yield. In other studies with the same trait definition and pricing system for milk yield, the milk yield $\mathrm{EW}$ was estimated to be $€ 0.12 / \mathrm{kg}$ (equivalent to $\$ 0.16$ ) for both the Czech Republic (Wolfová et al., 2007) and Hungarian (Komlósi et al., 2010) Holstein populations, which is in agreement with our results of $\$ 0.15$, on average. Most other studies have reported a negative EW for milk volume or carrier (Miglior et al., 2005) because of energy requirement costs for lactose production. When pricing systems are based on yields of milk fat and protein, there is no sale price for the carrier.

The relative importance of fat and protein yields depends strongly on the premium for milk fat and protein and on the feed costs. In situations in which both fat and protein percentages were included in the payment system, the relative EW for fat and protein yields varied under quota systems from 1:3 to 1:20, in comparison 
with the scenarios without quotas, where these ratios varied from 1:1.3 to 1:3.2, as reviewed by Wolfová et al. (2007). Due to higher costs than revenues for protein yield in the Iranian milk pricing system, the EV of protein yield in the present study was negative and this is not expected to change in the near future. Therefore, the economic impact of protein yield on the direction of genetic improvement will be limited.

The estimated EV for longevity was $\$ 10.43$ per month and per cow per year, on average, which, when corrected using a GE coefficient of 0.44 , resulted in an EW of $\$ 4.59$ per calf born for each additional month of longevity. In most other studies, EV for longevity, defined as productive life, were expressed per day. The values ranged from $\$ 0.12$ to $\$ 1.52$ per day in European countries, as reviewed by Komlósi et al., (2010). In the United States, EV for productive life was estimated to be $\$ 35$ per month (Cole and Van Raden, 2010), which is 3.4 times larger than our result. These differences can be attributed to differences in the model used, definition of the trait, as well as assumptions about management system.

The EV calculated for cow mature weight in this study was negative $(-\$ 1.58 / \mathrm{kg}$ per cow per year) and this fits into the reported range of $-\$ 1.73$ to $\$ 0.38 /$ $\mathrm{kg}$ per cow per year in the literature (Visscher et al., 1994; Koenen et al., 2000; Pérez-Cabal et al., 2006). However, these studies have only included the effect of heavier cows on feed costs for growth and maintenance and on revenues from slaughter cows. Including the effect of feed requirements for maintaining and growing the replacement heifer as in this study would make the calculation of EV for mature weight become even more negative. Interestingly, Vargas et al. (2002) and Kahi and Nitter (2004) derived positive EV for cow mature weight under marketing systems where the price of beef relative to feed was such that marginal revenue from increased live weight was more than the marginal costs of raising larger heifers and maintaining heavier lactating cows.

The EW calculated for direct stillbirth in this study was strongly negative. Direct stillbirth rate represented $8 \%$ of total importance in the proposed Iranian selection index. Miglior et al. (2005) reported the relative emphasis on traits in selection indices from 15 countries. No index placed any emphasis on stillbirth, even though increasing stillbirth rates have been reported in some Holstein populations, namely the Netherlands, United States, and Denmark. However, in the United States, calving ability subindex, sire and daughter calving ease and stillbirth have weightings with the ratio of 0.4:0.6, respectively (Cole and VanRaden, 2010).

The EW calculated for calving interval in this study showed the biggest variations among traits in the index.
The estimated EW was negative across all farms except 1 , for which a positive EW of $\$ 0.34$ per calving interval day per calf born was calculated. This was mainly because of low net income from calves and heifers on this farm; the high coefficient of variation of EV most likely reflects the low average EV for this trait. To avoid double counting, factors associated with longevity and NR56 were excluded from the calving interval EV in this study. Kahi and Nitter (2004) reported positive $\mathrm{EV}$ for calving interval. In their model, calving interval was only associated with the revenues from the sale of male calves and culled heifers, and heifer rearing costs.

Results from the present study indicate that age at first calving had a negative EW and contributed $8 \%$ of total importance in the index. Age at first calving is a heifer trait. Decreasing the age at first calving of a herd has an influence on the product output levels of a herd and the replacement rate. Inclusion of age at first calving in the breeding program will decrease the unproductive life of the cow and shorten the generation interval (Kahi and Nitter, 2004).

In the present study, EW for direct and maternal calving performance were expressed in terms of 1 percentage unit increase in cows experiencing difficult or very difficult calvings. In other studies, the definitions and units of the calving difficulty trait were very different; for example, for Spanish dairy cattle, the EV for direct calving difficulty was expressed per cow per calving interval per liability unit (López de Maturana et al., 2007), whereas in the Czech Republic, it was based on mean score per cow per year (Wolfová et al., 2007). Above-mentioned factors as well as the differences in production systems, market prices, and cost items considered make it impossible to compare our results with other studies.

The EW calculated for SCS showed the highest values and contributed $10 \%$ of total importance, making it the second most important trait in the index. Milk quality premium schemes vary among and within countries. In addition, the EV of SCS is strongly dependent on the population mean and methods. These factors result in considerable variation in the EV of SCS among different studies, as reviewed by Sadeghi-Sefidmazgi et al. (2011). Clinical mastitis is not systematically recorded in Iran. Resistance to mastitis may be added to the breeding objectives as a separate trait when data become available for genetic evaluations. Inclusion of both mastitis incidence and SCS would more efficiently improve resistance to mastitis and improve milk quality (Sender et al., 1992).

This paper also presented the development of EW for NR56. The NR56 is being used as an indicator of female fertility in national genetic evaluations in Canada, Great Britain, and the Netherlands (Jorjani, 2007). In 
Table 8. Relative emphasis (\%) of traits in selection indices of major exporter countries ${ }^{1}$ to Iran

\begin{tabular}{|c|c|c|c|c|c|}
\hline & United States & Canada & The Netherlands & Germany & Iran \\
\hline Production traits & 35 & 51 & 33 & 45 & 50 \\
\hline Fat yield & 19 & 20.4 & 4.8 & 9 & 8 \\
\hline Protein yield & 16 & 30.6 & 21.7 & 36 & -6 \\
\hline Durability traits & 39 & 34 & 42 & 35 & 14 \\
\hline Capacity (body size) & -6 & - & - & - & -7 \\
\hline Conformation (exterior traits) & - & 3.4 & 22 & 15 & - \\
\hline Health and reproduction traits & 26 & 15 & 25 & 20 & 36 \\
\hline Udder health (SCS) & -10 & 3 & 6 & 7 & -10 \\
\hline Fertility & 11 & 10.05 & 19 & 10 & 16 \\
\hline Calving ability $^{6}$ & -5 & - & - & 3 & -10 \\
\hline
\end{tabular}

${ }^{1}$ Figures in bold sum to $100 \%$ within trait group and country; values not in bold sum to the figures in bold.

${ }^{2}$ Cole and VanRaden (2010).

${ }^{3}$ Lifetime profit index (http://www.cdn.ca).

${ }^{4} \mathrm{DPS}=$ durable performance sum; RZG $=$ relativzuchtwert gesamt (total merit index).

${ }^{5}$ Lifetime net income index.

${ }^{6}$ Stillbirth rate and calving difficulty.

${ }^{7}$ Milking speed and udder depth.

the Netherlands, Van der Beek (1999) has predicted EW for NR56 to be Dutch florins (Dfl) 0.45 (equivalent to $\$ 0.28)$ /percentage unit per cow per year, which is a lower value than in results from the present study. In other words, a 1 percentage unit increase in NR56 makes each cow $\$ 0.28$ more profitable.

In the current Iranian breeding program for Holstein dairy cattle, independent culling levels are widely applied and these are mainly based on milk yield and type traits. However, this approach is unlikely to be optimal because genetic relationships among traits and their EW are not taken into account. Therefore, an attempt was made to calculate EW under Iranian conditions and propose a national genetic index. Table 8 shows the relative emphasis (\%) of traits in selection indices of major exporter countries to Iran. The majority of Holstein semen sires are imported from the United States, Canada, the Netherlands, and Germany. Milk carrier yield is not included or is even penalized in the index of these countries, whereas in our proposed selection index, BM yield is the most important trait. In the indices of exporting countries, the weight for protein yields ranges from 16 to $36 \%$, whereas protein yield has a negative weight of $-6 \%$ in the Iranian index. Durability group traits vary from 34 to $42 \%$ in the indices of exporting countries, whereas in the present study, it was only $14 \%$. This was mainly because of our low relative weight for longevity and an absence of weightings on type traits. The Iranian index suggested that most selection pressure would be on health and reproductive group traits $(36 \%)$, whereas in exporting countries, this emphasis varied from 15 to $26 \%$. Conformation traits can be used as predictors of health, calving ease, and efficiency (Forabosco et al., 2005). These traits are information traits, not breeding goal traits because they do not have any direct economic impacts on cow profitability. Therefore, in our proposed selection index, conformation traits were replaced by functional traits.

Average relative emphasis for production, durability, and health and reproduction, across all exporter countries, was $41,37.5$, and $21.5 \%$, respectively, whereas the respective values were 50,14 , and $36 \%$ for the Iranian index. Significant differences in selection indices decrease the utility of importation of semen as a means of achieving sustainable genetic progress in Iran. Results obtained in this study provide important information about EV of traits that can be used to improve progeny testing programs as well as importation rules for semen to Iran.

\section{ACKNOWLEDGMENTS}

The authors are grateful to the farmers for participating in the study and to the Animal Breeding Centre of Iran (Karaj, Iran) for generously providing the data. Special thanks are extended to Marie Wolfová from the Institute of Animal Science, Prague-Uhř́něves, Czech Republic for her critical comments. The helpful sugges- 
tions of 2 anonymous reviewers are gratefully acknowledged.

\section{REFERENCES}

Amer, P. R., G. Simm, M. G. Keane, M. G. Diskin, and B. W. Wickham. 2001. Breeding objectives for beef cattle in Ireland. Livest. Prod. Sci. 67:223-239.

Bekman, H., and J. A. M. van Arendonk. 1993. Derivation of economic values for veal, beef and milk production traits using profit equations. Livest. Prod. Sci. 34:35-56.

Byrne, T. J., P. R. Amer, P. F. Fennessy, A. R. Cromie, T. W. J. Keady, J. P. Hanrahan, M. P. McHugh, and B. W. Wickham. 2010. Breeding objectives for sheep in Ireland: A bio-economic approach. Livest. Sci. 132:135-144.

Coffey, E. M., W. E. Vinson, and R. E. Pearson. 1986. Potential of somatic cell concentration in milk as a sire selection criterion to reduce mastitis in dairy cattle. J. Dairy Sci. 69:2163-2172.

Cole, J. B., and P. M. VanRaden. 2010. Net merit as a measure of lifetime profit: 2010 revision. Accessed Feb. 12, 2010. http://aipl. arsusda.gov/reference/nmcalc-2010.htm.

Dadpasand, M., S. R. Miraei-Ashtiani, M. Moradi Shahrebabak, and R. Vaez Torshizi. 2008. Impact of conformation traits on functional longevity of Holstein cattle of Iran assessed by a Weibull proportional hazards model. Livest. Sci. 118:204-211.

Dadpasand-Taromsari, M. 2005. Comparison between different methods of genetic parameter estimations and genetic evaluation for productive life in Holstein dairy cattle of Iran. PhD Thesis. University of Tehran, Karaj, Iran.

Dematawewa, C. M., and P. J. Berger. 1997. Effect of dystocia on yield, fertility, and cow losses and an economic evaluation of dystocia scores for Holsteins. J. Dairy Sci. 80:754-761.

Dempster, E. R., and I. M. Lerner. 1950. Heritability of threshold characters. Genetics 35:212-236.

Forabosco, F., R. Bozzi, P. Boettcher, F. Filippini, P. Bijma, and J. A. M. Van Arendonk. 2005. Relationship between profitability and type traits and derivation of economic values for reproduction and survival traits in Chianina beef cows. J. Anim. Sci. 83:2043-2051.

Gibson, J. P. 1989. Economic weights and index selection of milk production traits when multiple production quotas apply. Anim. Prod. 49:171-181.

González-Recio, O., and R. Alenda. 2005. Genetic parameters for female fertility traits and a fertility index in Spanish dairy cattle. J. Dairy Sci. 88:3282-3289.

Groen, A. F. 1989. Cattle breeding goals and production circumstances. PhD Thesis. Wageningen Agricultural Univ., Wageningen, the Netherlands.

Groen, A. F., T. Steine, J. Colleau, J. Pedersen, J. Pribyl, and N. Reinsch. 1997. Economic values in dairy cattle breeding, with special reference to functional traits. Report of an EAAP-working group. Livest. Prod. Sci. 49:1-21.

Hansen, M., M. S. Lund, J. Pedersen, and L. G. Christensen. 2004. Genetic parameters for stillbirth in Danish Holstein cows using a Bayesian threshold model. J. Dairy Sci. 87:706-716.

Hazel, L. N., and J. L. Lush. 1942. The efficiency of three methods of selection. J. Hered. 33:393-399.

Jorjani, H. 2007. International genetic evaluation of female fertility traits in five major breeds. Interbull Bull. 37:144-147.

Kahi, A. K., and G. Nitter. 2004. Developing breeding schemes for pasture based dairy production systems in Kenya I. Derivation of economic values using profit functions. Livest. Prod. Sci. 88:161-177.

Koenen, E. P. C., P. B. M. Berentsen, and A. F. Groen. 2000. Economic values of live weight and feed-intake capacity of dairy cattle under Dutch production circumstances. Livest. Prod. Sci. 66:235-250.

Komlósi, I., M. Wolfová, J. Wolf, B. Farkas, Z. Szendrei, and B. Béri. 2010. Economic weights of production and functional traits for Holstein-Friesian cattle in Hungary. J. Anim. Breed. Genet. 127:143-153.
López de Maturana, E., E. Ugarte, J. Komen, and J. A. M. van Arendonk. 2007. Consequences of selection for yield traits on calving ease performance. J. Dairy Sci. 90:2497-2505.

Meijering, A. 1986. Dystocia in dairy cattle breeding with special attention to sire evaluation for categorical traits. PhD Thesis. Wageningen Agricultural Univ., Wageningen, the Netherlands.

Miglior, F., B. L. Muir, and B. J. Van Doormaal. 2005. Selection indices in Holstein cattle of various countries . J. Dairy Sci. 88:12551263.

NRC. 2001. Nutrient Requirements of Dairy Cattle. 6th rev. ed. Natl. Acad. Sci., Washington, DC.

Nilforooshan, M. A., and M. A. Edriss. 2004. Effect of age at first calving on some productive and longevity traits in Iranian Holsteins of the Isfahan province. J. Dairy Sci. 87:2130-2135.

Pérez-Cabal, M. A., R. González Santillana, and R. Alenda. 2006. Mature body weight and profit selection in Spanish dairy cattle. Livest. Sci. 99:257-266.

Sadeghi-Sefidmazgi, A., M. Moradi-Shahrbabak, A. Nejati-Javaremi, S. R. Miraei-Ashtiani, and P. R. Amer. 2011. Estimation of economic values and financial losses associated with clinical mastitis and somatic cell score in Holstein dairy cattle. Animal 5:33-42.

Sadeghi-Sefidmazgi, A., M. Moradi-Shahrbabak, A. Nejati-Javaremi, and A. Shadparvar. 2009. Estimation of economic values in three breeding perspectives for longevity and milk production traits in Holstein dairy cattle in Iran. Ital. J. Anim. Sci. 8:359-375.

Sender, G., J. Juga, T. Hellman, and H. Saloniemi. 1992. Selection against mastitis and cell count in dairy cattle breeding programs. Acta Agric. Scand. A Anim. Sci. 42:205-210.

Shadparvar, A., N. Emmanjomeh, and A. Chizari. 1997. Investigation of economic weights for milk yield, fat percentage and herdlife in Holstein dairy cattle of Iran. J. Sci. Agric. Indust. 11:93-108. (In Farsi).

Toghiani Pozveh, S., A. Shadparvar, M. Moradi Shahrbabak, and M. Dadpasand Taromsari. 2009. Genetic analysis of reproduction traits and their relationship with conformation traits in Holstein cows. Livest. Sci. 125:84-87.

Van der Beek, S. 1999. Breeding for profit in the Netherlands. Interbull Bull. 23:75-78.

Vargas, B., A. F. Groen, M. Herrero, and J. A. M. Van Arendonk. 2002. Economic values for production and functional traits in Holstein cattle of Costa Rica. Livest. Prod. Sci. 75:101-116.

Visscher, P. M., P. J. Bowman, and M. E. Goddard. 1994. Breeding objectives for pasture based dairy production systems. Livest. Prod. Sci. 40:123-137.

Wolfová, M., J. Wolf, J. Kvapilík, and J. Kica. 2007. Selection for profit in cattle: I. Economic weights for purebred dairy cattle in the Czech Republic. J. Dairy Sci. 90:2442-2455.

\section{APPENDIX}

\section{Profit from Calves}

In Iranian dairy farms, there are no sales of female calves, except those culled involuntarily. Both male and female calves up to 3 mo may be culled involuntarily because of poor health or through selection for genetic improvement. Male calves are sold to feedlots for finishing either for a fixed price per animal if voluntarily culled, otherwise or alternatively at a price expressed per kilogram of live weight.

Revenues for calves $\left(R_{1}\right)$ were calculated as

$$
\begin{gathered}
\mathrm{R}_{1}=\mathrm{NCR} 3 \mathrm{M} \times \mathrm{CICR} \times \mathrm{CFLW} \times p l w_{1} \\
+\mathrm{CVCR} \times b c p,
\end{gathered}
$$


where NCR3M is the number of male and female calves reared to 3 mo of age per cow per year, CICR is the involuntary culling rate of calves from birth to 3 mo of age (the same for male and female calves), CFLW is the live weight $(\mathrm{kg})$ of a culled calf, $p l w_{1}$ is the price per kilogram of CFLW (\$), CVCR is the proportion of male calves sold to feedlots and calculated as $0.5 \times \mathrm{NCR} 3 \mathrm{M}$ $\times(1-\mathrm{CICR})$, and $b c p$ is the male calf price $(\$ /$ calf $)$.

The NCR3M was calculated as $(1-\mathrm{SB}) \times(1-\mathrm{CMo})$ $\times 365 /$ calving interval $(\mathrm{ClvI}, \mathrm{d})$, which shows the number of offspring per cow per year, assuming equal sex ratio of 0.5 for males and females and multiplied by the proportion of cows that calve per year $(365 / \mathrm{ClvI})$; SB is stillbirth rate; and $\mathrm{CMo}$ is calf mortality.

Costs for calves $\left(\mathrm{C}_{1}\right)$ were calculated as

$$
\begin{aligned}
\mathrm{C}_{1}=[1- & (0.75 \times \mathrm{SB}+0.5 \times \mathrm{CMo})] \\
\times & \times 365 / \mathrm{ClvI} \times \mathrm{crc},
\end{aligned}
$$

where crc is the calf-rearing costs $(\$ /$ calf) and assumed costs for stillborn calves and dead calves are 0.25 and 0.5 of total surviving calf-rearing costs, respectively.

\section{Profit from Heifers}

This group includes females from age 3 mo to age at first calving or to selling as breeding animals or to culling. A percentage of heifers are sold as replacements to other herds. A small percentage of heifers are culled because of infertility and other diseases. Remaining heifers are used for replacement in their own herd.

Revenues for heifers $\left(R_{2}\right)$ were calculated as

$$
\begin{gathered}
\mathrm{R}_{2}=[\mathrm{NHR} \times \mathrm{SR} \times(1-\mathrm{HCR})-1 / \mathrm{L}] \times r h p \\
+\mathrm{NHR} \times \mathrm{SR} \times \mathrm{HCR} \times \mathrm{CHLW} \times p l w_{2},
\end{gathered}
$$

where NHR is the number of female calves reared per cow per year and calculated as the same as the CVCR; $\mathrm{L}$ is longevity, expressed as the average number of years of life from first calving to death per cow; SR is the survival rate of heifers from 3 mo of age to calving; HCR is the involuntary culling rate of all reared female calves; $r h p$ is the replacement heifer's price $(\$ /$ heifer); CHLW is the live weight of culled heifers $(\mathrm{kg})$; and $p l w_{2}$ is the price per kilogram of CHLW (\$).
Costs for heifers $\left(\mathrm{C}_{2}\right)$ were calculated as

$$
\begin{aligned}
\mathrm{C}_{2}=1 / \mathrm{L} & \times h r c+[(\mathrm{NHR} \times \mathrm{SR})-1 / \mathrm{L}] \times s b h r c \\
& +\mathrm{NHR} \times(1-\mathrm{SR}) \times d h r c,
\end{aligned}
$$

where $h r c$ is the rearing costs from 3 mo of age to calving (\$/heifer); sbhrc is the rearing costs from 3 to $23 \mathrm{mo}$ of age $(\$ /$ heifer $)$; and $d h r c$ is the rearing costs per heifer dead, assumed to be $0.25 \mathrm{hrc}$.

\section{Profit from Cows}

This group includes cows from first calving (at about 26 mo of age) until culling. Cows include milking and dry cows. Average productive lifetime of cows is 2.7 lactations in the whole Holstein population of Iran. Average weight at culling (mature weight) is $680 \mathrm{~kg}$.

Revenues for cows $\left(R_{3}\right)$ were calculated as

$$
\begin{gathered}
\mathrm{R}_{3}=\mathrm{MY} \times(p b m-C s c s)+(\mathrm{FY}-\mathrm{FYB}) \times p a f \\
+(\mathrm{PY}-\mathrm{PYB}) \times p a p+(1-\mathrm{PCM}) \\
\times 1 / \mathrm{L} \times \mathrm{CCLW} \times p l w_{3},
\end{gathered}
$$

where MY, FY, and PY are 305-d milk, fat, and protein yields $(\mathrm{kg})$, respectively; $p b m$ is the price per kilogram of BM with $3.2 \%$ fat and $3 \%$ protein $(\$ / \mathrm{kg})$; Cscs is the costs associated with the lactation SCS $(\$ / \mathrm{kg})$; FYB is the $\mathrm{BM}$ fat content $(\mathrm{kg})$, calculated as $\mathrm{MY} \times 0.032$; PYB is the BM protein content $(\mathrm{kg})$, calculated as MY $\times 0.03$; paf is an accessory payment for each kilogram of milk fat; pap is an accessory payment for each kilogram of milk protein; PCM is the productive cow mortality rate; CCLW is the average live weight $(\mathrm{kg})$ of a culled cow; and $p l w_{3}$ is the price per kilogram of CCLW (\$).

Costs for cows $\left(\mathrm{C}_{3}\right)$ were calculated as

$$
\begin{aligned}
& \mathrm{C}_{3}=\mathrm{MY} \times c b m+(\mathrm{FY}-\mathrm{FYB}) \times c a f \\
& +(\mathrm{PY}-\mathrm{PYB}) \times c a p+C c m+C d y s
\end{aligned}
$$

where $c b m$ is the BM costs $(\$ / \mathrm{kg})$; caf is the accessory cost for each kilogram of milk fat $(\$ / \mathrm{kg})$; cap is the accessory cost for each kilogram of milk protein $(\$ / \mathrm{kg})$; $\mathrm{Ccm}$ is the cost of CM; and Cdys is the cost of calving difficulty. 